\title{
RECOMMENDATIONS TO BIS FOR UNREINFORCED CFST COLUMNS UNDER AXIAL LOADING
}

\author{
Shamli V. Janjal \\ Student, M. Tech (Structural) \\ Department of Applied Mechanics, \\ GCE Karad, Maharashtra, India
}

\author{
M. R. Shiyekar \\ Professor, \\ Department of Applied Mechanics, \\ GCE Karad, Maharashtra, India
}

\author{
Y. M. Ghugal \\ Head, \\ Department of Applied Mechanics, \\ GCE Karad, Maharashtra, India
}

\begin{abstract}
This paper presents the analytical and finite element behaviour of short and long concrete-filled steel tube i.e. CFST columns. The objective is to compare the behaviour of CFST columns of circular and square cross sections under concentric axial loading. The load deformation characteristics were studied for different grades of concrete. The axial load carrying capacity for limit state of strength for both short and long CFST columns were tested in yielding and buckling respectively. The 8 noded 3D solid elements were used for finite element meshing in ANSYS-Workbench software. The research finding indicates that the circular cross section of CFST column is effective in resisting axial deflection as well as strength compared to square cross section having equal steel material.
\end{abstract}

Keywords-Concrete-filled steel tube, axial loading, Finite Element, Yielding, Buckling.

\section{INTRODUCTION}

The CFST column is formed by filling the concrete in the thin steel tube with or without reinforcement. The concrete-filled steel tube (CFST) columns utilize the advantage of both steel and concrete. CFST columns are currently being increasingly used in the construction of buildings, due to their excellent static and earthquake resistant properties, such as high strength, large energy absorption capacity, bending stiffness, high ductility, fire performance along with favourable construction ability, etc. In current international practice, concrete-filled steel tube (CFST) columns are used in the primary lateral resistance systems of both braced and unbraced building structures. There exist applications in Japan and Europe where CFSTs are also used as bridge piers. The CFST structural member has a number of distinct advantages over equivalent steel, reinforced concrete, or steel-reinforced concrete member. The orientation of the steel and concrete in the cross section optimizes the strength and rigidity of the section. Steel is in the outer perimeter, where it performs more effectively in tension and in resisting a moment of bending. Steel, which has a much greater modulus of elasticity than concrete gives more contributions to the moment of inertia, is situated farthest from the centroid hence the stiffness of CFST column is greatly enhanced. Concrete forms an ideal core to withstand the compression load in typical applications, and delays and often prevents local steel buckling. The more fragile nature of high strength concrete is partially mitigated by the confinement of the steel pipe, and the local buckling of the thin steel pipe is delayed due to the support offered by the concrete when high strength concrete and thin-walled steel tubes are used together. Axially loaded columns, CFST beam-columns connections, have been studied worldwide and to some extent, many of the aforementioned issues have been reconciled for these types of members. This paper shows the comparison of a circular and square CFST column with varying grades of concrete $(30,50$, $70 \mathrm{~N} / \mathrm{mm} 2$ ) and for axial load, for their ultimate load carrying capacity and deformation.

\section{METHODOLOGY}

\section{A. Finite Element Analysis -}

Recently, the software uses the Finite element method for the analysis and design of the structure. In ANSYS Workbench, analyses are created as systems, which can be combined in a project. The project is driven by a schematic workflow that manages connections between systems. The study involves the use of ANSYS workbench (16.0) software for analysis.

\section{B. Material Specification -}

Multi-linear property of concrete and bilinear properties for steel tube is used. The modulus of elasticity of concrete is taken as $5000 \sqrt{ } f c k$ according to IS $456: 2000$, where $f_{c k}$ is characteristic strength of concrete

- $\quad$ Structural steel property

$$
\begin{aligned}
& \text { Density }-7850 \mathrm{~kg} / \mathrm{m}^{3} \\
& \text { Young's modulus }-2 \times 10^{5} \mathrm{~N} / \mathrm{mm}^{2}
\end{aligned}
$$




\section{International Journal of Engineering Applied Sciences and Technology, 2019 \\ Vol. 4, Issue 3, ISSN No. 2455-2143, Pages 85-93 \\ Published Online July 2019 in IJEAST (http://www.ijeast.com)}

Yield strength $-250 \mathrm{~N} / \mathrm{mm}^{2}$

Poisson's ratio -0.3

- $\quad$ Concrete property

Density $-2400 \mathrm{~kg} / \mathrm{m}^{3}$

Young's modulus - 5000 $\sqrt{ } c k$

Compressive cube strength $-30,50,70 \mathrm{~N} / \mathrm{mm}^{2}$

Poisson's ratio -0.18

\section{Geometric Specifications -}

Table - 1 Geometric Specifications of the model

\begin{tabular}{|c|c|c|}
\hline Parameters & Circular & Square \\
\hline Outer dimension $(\mathbf{m m})$ & 200 & 177 \\
\hline Inner dimension(mm) & 186 & 164.6 \\
\hline $\begin{array}{c}\text { Thickness of steel } \\
\text { tube(mm) }\end{array}$ & 7 & 6.2 \\
\hline Length of column(mm) & $\begin{array}{c}2000,3000 \\
4000\end{array}$ & $\begin{array}{c}2000,3000, \\
4000\end{array}$ \\
\hline
\end{tabular}

\section{FE Modelling and Meshing -}

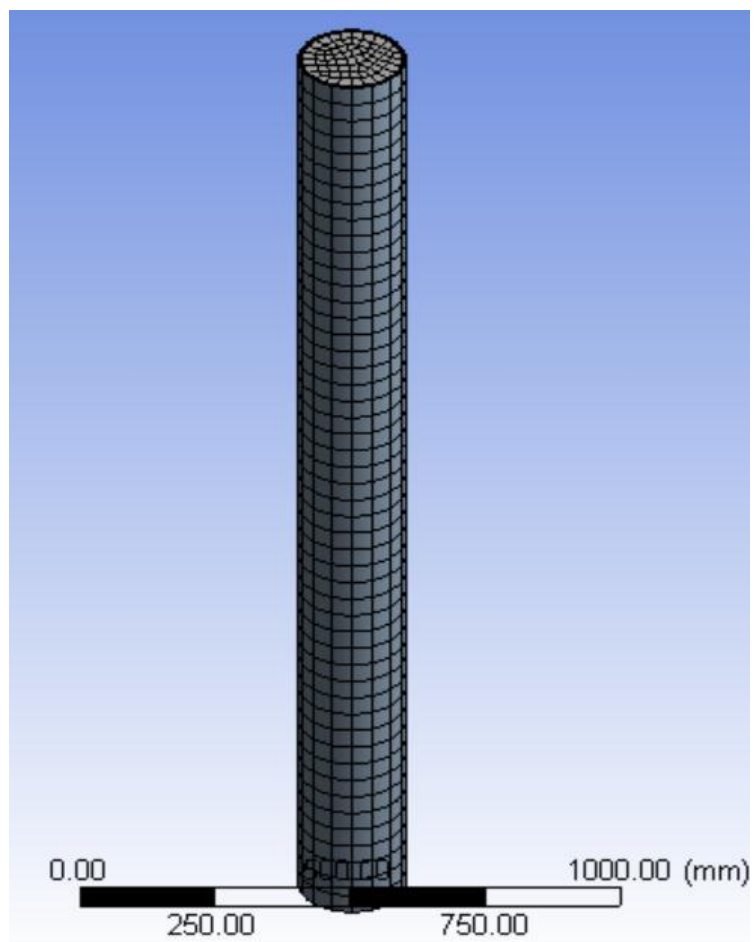

Fig.1. Meshing of circular CFST column

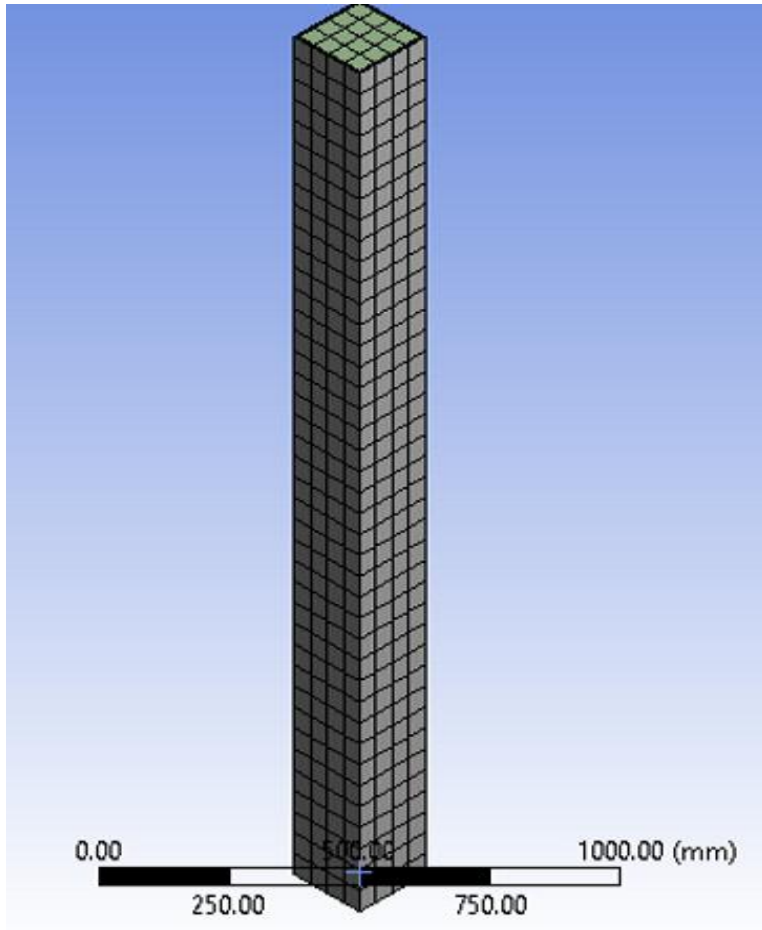

Fig.2. Meshing of square CFST column

\section{E. Boundary Conditions -}

For each of the two extremes, two different types of boundary conditions were used. At the fixed lower end, the degrees of freedom of movement in the directions X, Y, Z (U1, U2, U3), as well as the degrees of freedom of rotation in the $\mathrm{X}, \mathrm{Y}, \mathrm{Z}$ directions were restricted to zero. At the top end is the roller support. The translation of U2 (Y) is free whereas remaining $\mathrm{U} 1, \mathrm{U} 3$ are restricted and the degrees of freedom of rotation are free.

\section{F. Contact between Steel Tube and Concrete -}

The contact between the concrete filling and the steel pipe is given such that it always has bonded contact and the space between the steel pipe and the concrete filling is always closed and not allowed to penetrate each other.

\section{G. Comparison of different International codes -}

1. Yielding load calculation for short columns (AISC/LFRD)

The axial strength of a composite element is computed similar to that of a structural steel column, except the material yield strength and stiffness are modified to account for the steel and concrete components in the composite column. The 


\section{International Journal of Engineering Applied Sciences and Technology, 2019 \\ Vol. 4, Issue 3, ISSN No. 2455-2143, Pages 85-93 \\ Published Online July 2019 in IJEAST (http://www.ijeast.com)}

AISC/LRFD defines the square of the column slenderness parameter as:

$$
\lambda^{2}=F_{m y} / F_{E}=\left(K L / r_{m} \pi\right)^{2}\left(F_{m y} / E_{m}\right)
$$

Where, $F_{E}$ - Euler's buckling stress for a column; $r_{m}$ - Radius of gyration of the steel tube only; and KL - Effective simply supported column length. $\mathrm{E}_{\mathrm{m}}$ is the Modified elastic modulus and $F_{m y}$ is the Modified yield strength of the CFST column which is defined by the equations:

$$
\begin{aligned}
& \mathrm{E}_{\mathrm{m}}=\mathrm{E}_{\mathrm{s}}+0.40 \mathrm{E}_{\mathrm{c}}\left(\mathrm{A}_{\mathrm{c}} / \mathrm{A}_{\mathrm{s}}\right) \\
& \mathrm{F}_{\mathrm{my}}=\mathrm{F}_{\mathrm{y}}+0.85 f^{\prime}{ }_{c k}\left(\mathrm{~A}_{\mathrm{c}} / \mathrm{A}_{\mathrm{s}}\right)
\end{aligned}
$$

$\mathrm{E}_{\mathrm{s}}, \mathrm{A}_{\mathrm{s}}$ and Fy - Elastic modulus, Cross-sectional area, and the Yield strength of the steel tube, respectively; $\mathrm{E}_{\mathrm{c}}, \mathrm{A}_{\mathrm{c}}$, and $f_{c k}^{\prime}$ Elastic modulus, Area, and Strength of the concrete core, respectively. Once the column slenderness parameter is known the critical stress $\mathrm{F}_{\mathrm{cr}}$ is computed from:

$$
\begin{array}{cc}
\mathrm{F}_{\mathrm{cr}}=\left(0.658^{\lambda^{2}}\right) \mathrm{F}_{\mathrm{my}} & \text { for } \quad \lambda_{c} \leq 1.5 \\
\mathrm{~F}_{\mathrm{cr}}=\left(0.877 / \lambda^{2}{ }_{c}\right) \mathrm{F}_{\mathrm{my}} & \text { for } \lambda_{c}>1.5
\end{array}
$$

The ultimate strength of the CFST is determined by multiplying the critical stress by the cross-sectional area of the steel tube:

$$
\mathrm{P}_{\mathrm{cr}}=\mathrm{A}_{\mathrm{s}} \mathrm{F}_{\mathrm{cr}}
$$

2. Buckling load calculation for long columns (AISC/LRFD)

The ultimate axial crushing load is:

$$
\mathrm{P}_{0}=0.95 f_{c k} \mathrm{~A}_{\mathrm{c}}+\mathrm{f}_{\mathrm{y}} \mathrm{A}_{\mathrm{s}}
$$

Effective Stiffness,

$$
\mathrm{EI}_{\mathrm{eff}}=\mathrm{E}_{\mathrm{s}} \mathrm{I}_{\mathrm{s}}+\mathrm{C}^{\prime} \mathrm{E}_{\mathrm{c}} \mathrm{I}_{\mathrm{c}}
$$

Where, $C^{\prime}$ is effective stiffness factor given as:

$$
C^{\prime}=0.15+P / P_{0}+A_{s} /\left(A_{s}+A_{c}\right)
$$

Columns are analysed by Euler Formula:

Critical Load,

$$
P_{c r}=\frac{\pi^{2} E I_{e f f}}{L_{e f f}^{2}}
$$

Where,

$f_{c k}$ - Compressive cube strength of concrete

$\mathrm{A}_{\mathrm{s}}, \mathrm{A}_{\mathrm{c}}-$ cross sectional area of steel tube and concrete respectively

$\mathrm{P}$ - Applied axial load

$\mathrm{L}_{\text {eff }}$ - Effective buckling length of column

Models were verified with the theoretical Euler's critical buckling load formula.

\section{Buckling load calculation (EUROCODE 4)}

The axial force Nsdand the maximum end moment Msd are determined from a first order structural analysis. For each of the bending axes of the column it has to be verified that:

$$
\mathrm{N}_{\mathrm{sd}} \leq \chi \mathrm{kN}_{\mathrm{o}}
$$

Where, $\chi \mathrm{k}$ is a reduction factor due to buckling.

The buckling curves can also be described in the form of an equation:

$$
\begin{gathered}
\chi_{k}=\frac{1}{\phi+\sqrt{\phi^{2}-\bar{\lambda}^{2}}} \\
\text { Where, } \phi=0.5\left[1+\alpha(\bar{\lambda}-0.2)+\bar{\lambda}^{2}\right]
\end{gathered}
$$

Where $\alpha$ depends on the buckling effects, a value of 0.21 was adopted for CFST column. The relative slenderness of $\lambda$ is given by:

$$
\bar{\lambda}=\sqrt{\frac{N_{o}}{N_{c r}}}
$$

In which Ncr is the critical buckling stress resultant given by:

$$
N_{c r}=\frac{\pi^{2}(E I)_{e}}{L_{e}^{2}}
$$

Where Le is the effective length and $(\mathrm{EI})_{\mathrm{e}}$ is the actual elastic stiffness

$$
(\mathrm{EI})_{\mathrm{e}}=\mathrm{E}_{\mathrm{s}} \mathrm{I}_{\mathrm{s}}+0.8\left(\mathrm{E}_{\mathrm{c}} / 1.35\right) \mathrm{I}_{\mathrm{c}}
$$

4. Yielding load calculation (EUROCODE 4)

$$
P_{n}=A_{s} \cdot F_{c r}
$$

$$
\left.\begin{array}{ll}
\left(0.658^{\lambda^{2}}\right) \mathrm{F}_{\mathrm{my}} & \text { for } \lambda_{c} \leq 1.5 \\
\left(0.877 / \lambda^{2}{ }_{c}\right) \mathrm{F}_{\mathrm{my}} & \text { for } \lambda_{c}>1.5
\end{array}\right\} \mathrm{F}_{\mathrm{cr}}
$$

$$
\begin{gathered}
\lambda_{c}=\frac{K L}{r_{m} \pi} \sqrt{\frac{F_{m y}}{E_{m}}} \\
\mathrm{~F}_{\mathrm{my}}=\mathrm{f}_{\mathrm{y}}+0.85 \mathrm{fc}^{1}\left(\mathrm{~A}_{\mathrm{c}} / \mathrm{A}_{\mathrm{z}}\right) \\
\mathrm{E}_{\mathrm{m}}=\mathrm{E}_{\mathrm{z}}+0.4\left(\mathrm{~A}_{\mathrm{c}} / \mathrm{A}_{\mathrm{z}}\right) \mathrm{E}_{\mathrm{c}} \\
\mathrm{E}_{\mathrm{c}}=\mathrm{W}^{1.5} \mathrm{ffc}_{\mathrm{fc}}
\end{gathered}
$$


International Journal of Engineering Applied Sciences and Technology, 2019

Vol. 4, Issue 3, ISSN No. 2455-2143, Pages 85-93

Published Online July 2019 in IJEAST (http://www.ijeast.com)

III. RESULTS AND DISCUSSION

The deformation behaviour of short CFST columns $(\mathrm{L}=2000 \mathrm{~mm})$ under different loadings is shown in the table below:

Table - 2 Deformation behaviour of short CFST columns

\begin{tabular}{|c|c|c|}
\hline \multirow{2}{*}{ Load (kN) } & \multicolumn{2}{|c|}{ Deformation (mm) } \\
\cline { 2 - 3 } & Circular & Square \\
\hline \multirow{2}{*}{1000} & 1.377 & 1.381 \\
\hline 2000 & 2.754 & 2.762 \\
\hline 3000 & 4.132 & 4.143 \\
\hline
\end{tabular}

Table - 3 Deformation behaviour for different concrete grades

\begin{tabular}{|c|c|c|}
\hline \multirow{2}{*}{$\begin{array}{c}\text { Concrete Strength } \\
(f c k)\end{array}$} & \multicolumn{2}{|c|}{ Deformation (mm) } \\
\cline { 2 - 3 } & Circular c/s & Square c/s \\
\hline M30 & 1.377 & 1.381 \\
\hline M50 & 1.152 & 1.155 \\
\hline M70 & 1.035 & 1.037 \\
\hline
\end{tabular}

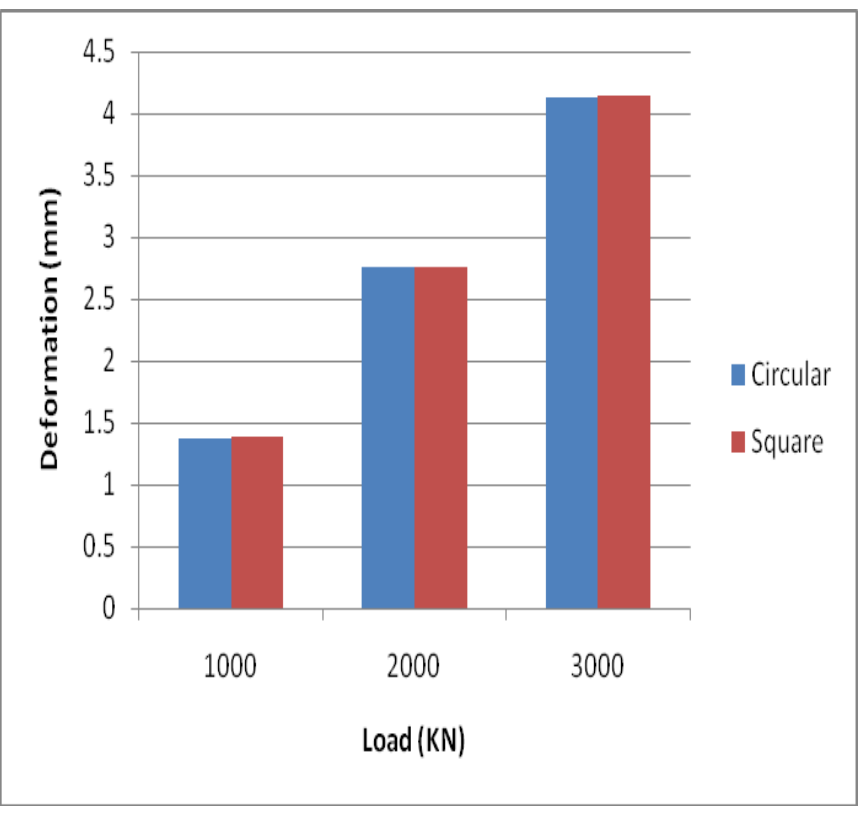

Chart 1. Deformation behaviour of short CFST column

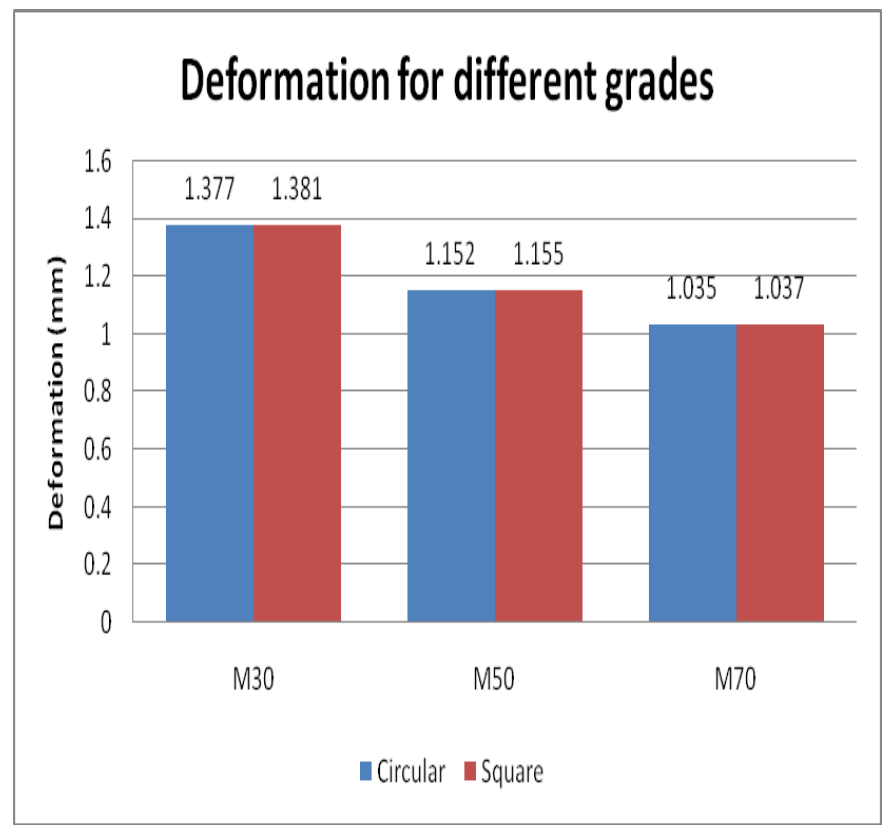

Chart 2. Deformation behaviour for different concrete grades 
International Journal of Engineering Applied Sciences and Technology, 2019

Vol. 4, Issue 3, ISSN No. 2455-2143, Pages 85-93

Published Online July 2019 in IJEAST (http://www.ijeast.com)

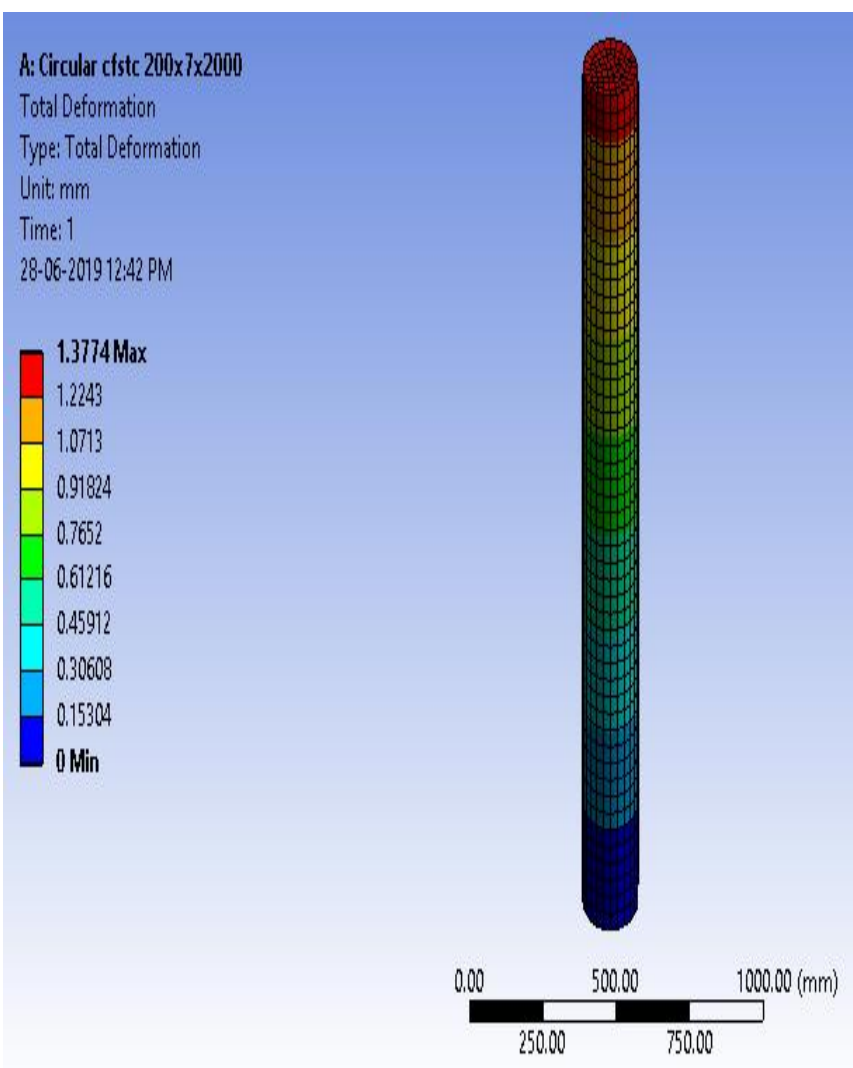

Fig. 3. Deformation behaviour of short CFST column

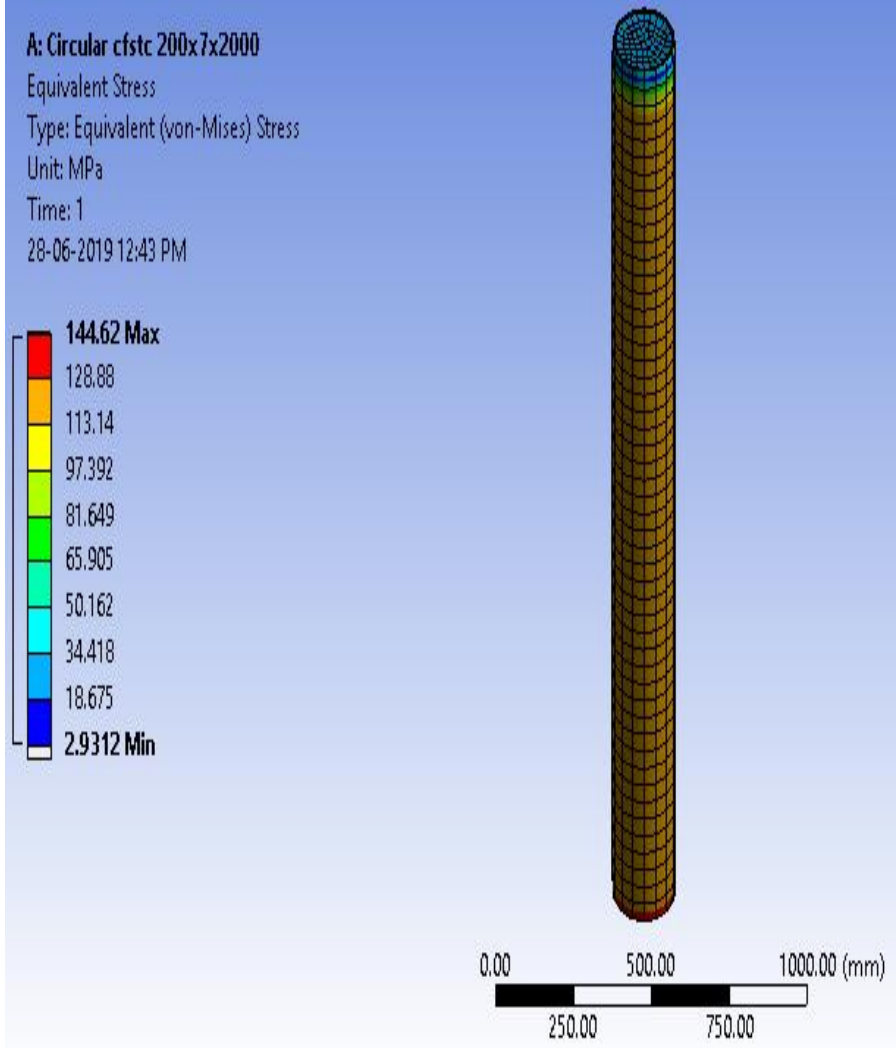

Fig. 4. Stress behaviour of short CFST column

Table - 4 Stress and strain behaviour of CFST short columns for different loads (M30)

\begin{tabular}{|c|c|c|c|c|c|c|c|c|}
\hline \multirow{3}{*}{$\begin{array}{c}\text { Load } \\
(\mathbf{k N})\end{array}$} & \multicolumn{4}{|c|}{ Stress (MPa) } & \multicolumn{4}{|c|}{ Strain } \\
\hline & \multicolumn{2}{|c|}{ Circular c/s } & \multicolumn{2}{|c|}{ Square c/s } & \multicolumn{2}{|c|}{ Circular c/s } & \multicolumn{2}{|c|}{ Square c/s } \\
\hline & Concrete & Steel & Concrete & Steel & Concrete & Steel & Concrete & Steel \\
\hline 1000 & 35.12 & 144.62 & 37.16 & 158.45 & 0.00141 & 0.00072 & 0.00149 & 0.00080 \\
\hline 2000 & 70.239 & 289.24 & 74.32 & 316.89 & 0.00282 & 0.00144 & 0.00289 & 0.00161 \\
\hline 3000 & 105.36 & 433.87 & 111.49 & 475.34 & 0.00423 & 0.00217 & 0.00448 & 0.00242 \\
\hline
\end{tabular}


International Journal of Engineering Applied Sciences and Technology, 2019

Vol. 4, Issue 3, ISSN No. 2455-2143, Pages 85-93

Published Online July 2019 in IJEAST (http://www.ijeast.com)

A. Critical load calculations for short CFST columns

\begin{tabular}{|c|c|c|c|c|c|}
\hline Type of c/s & $\begin{array}{c}\text { Critical load in } \\
\text { yielding(FEM) kN }\end{array}$ & $\begin{array}{r}\text { Critical load in } \\
\text { yielding(AISC) } k N\end{array}$ & $\begin{array}{l}\text { \% Difference } \\
\text { with FEM }\end{array}$ & $\begin{array}{c}\text { Critical load in } \\
\text { yielding(Eurocode 4) } \mathrm{kN}\end{array}$ & $\begin{array}{l}\text { \% Difference } \\
\text { with FEM }\end{array}$ \\
\hline Circular & 1725 & 1740 & $-0.8 \%$ & 1700 & $1.14 \%$ \\
\hline Square & 1680 & 1700 & $-1.19 \%$ & 1650 & $1.78 \%$ \\
\hline
\end{tabular}

Table - 5 Critical load in yielding for short column $(\mathrm{L}=2000 \mathrm{~mm})$

\section{Comparison of critical load}

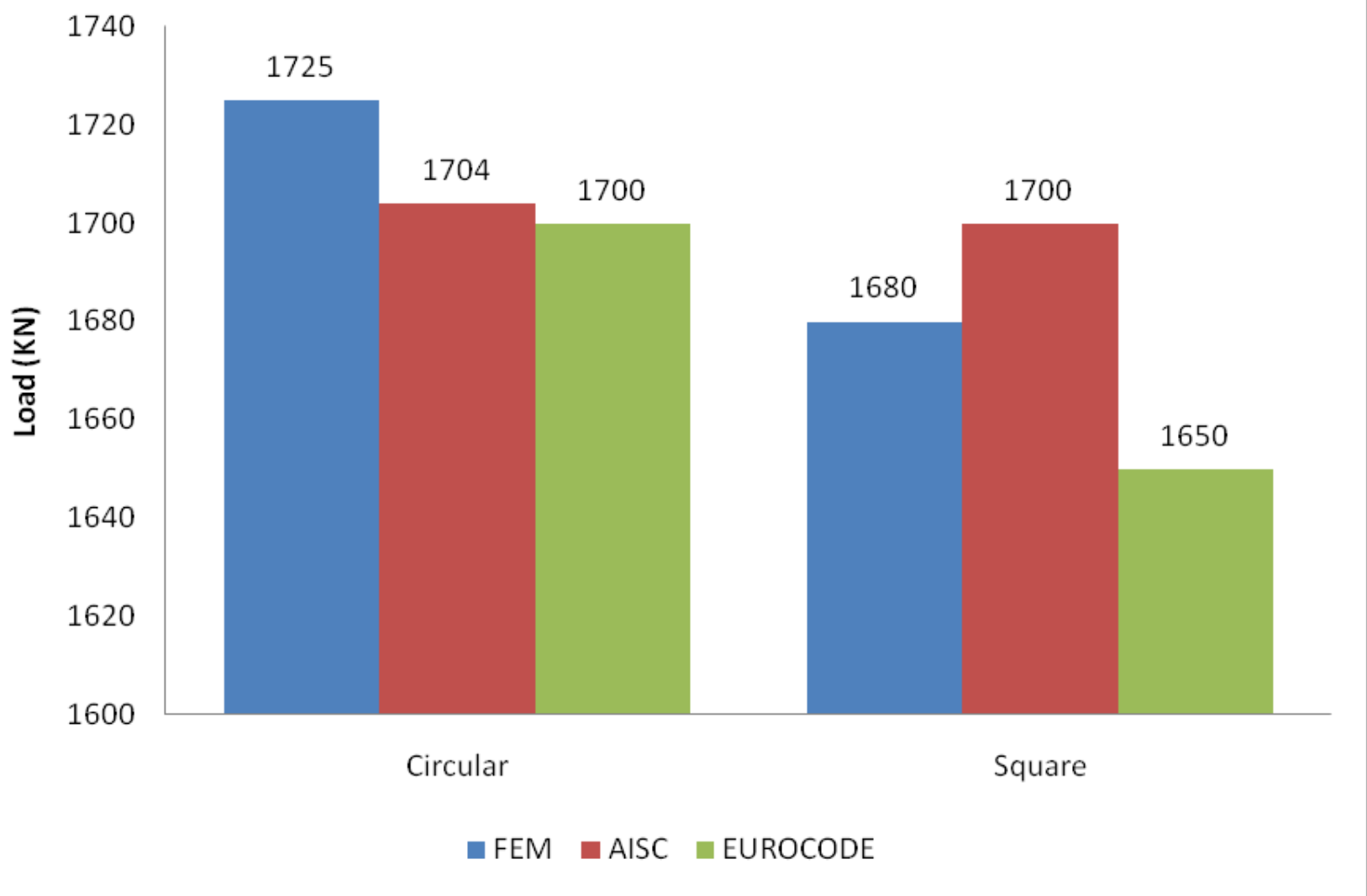

Chart 3. Critical load comparisons of short CFST columns 
International Journal of Engineering Applied Sciences and Technology, 2019

Vol. 4, Issue 3, ISSN No. 2455-2143, Pages 85-93

Published Online July 2019 in IJEAST (http://www.ijeast.com)

B. Critical load calculations for slender CFST columns

Table - 6 Critical load in buckling for slender column $(\mathrm{L}=3000 \mathrm{~mm})$

\begin{tabular}{|c|c|c|c|c|c|}
\hline Type of $\mathrm{c} / \mathrm{s}$ & $\begin{array}{l}\text { Critical load in buckling } \\
\text { (FEM) kN }\end{array}$ & $\begin{array}{l}\text { Critical load in buckling } \\
\text { (AISC) } \mathrm{kN}\end{array}$ & $\begin{array}{l}\% \text { Difference } \\
\text { with FEM }\end{array}$ & $\begin{array}{c}\text { Critical load in } \\
\text { buckling } \\
\text { (Eurocode 4) kN }\end{array}$ & $\begin{array}{l}\text { \% Difference } \\
\text { with FEM }\end{array}$ \\
\hline Circular & 11009 & 11353 & $-3.12 \%$ & 10589 & $3.81 \%$ \\
\hline Square & 11473 & 12000 & $-4.59 \%$ & 11197 & $2.40 \%$ \\
\hline
\end{tabular}

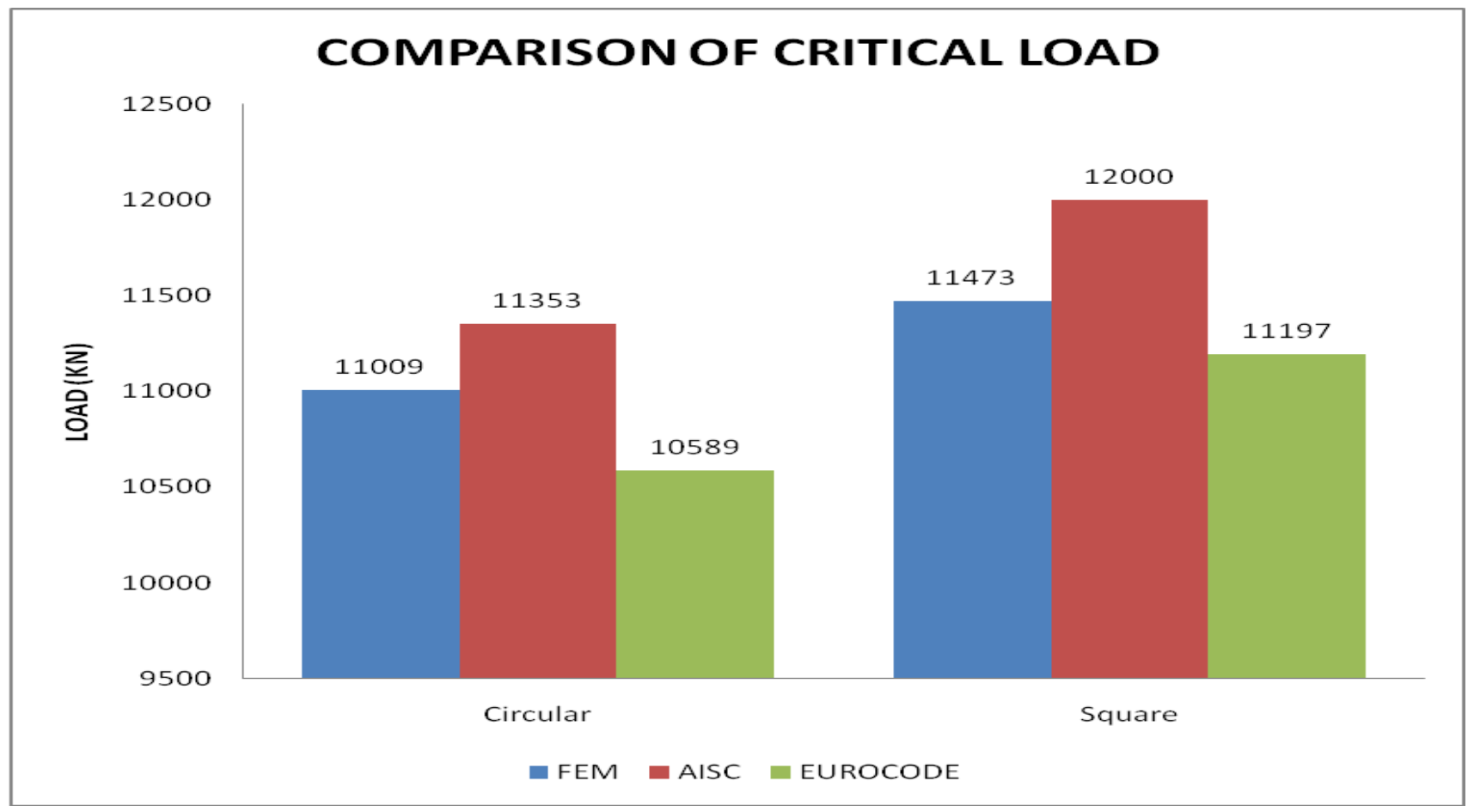

Chart 4. Critical load comparisons of slender CFST columns (L=3000mm)

Table -7 Critical load in buckling for slender column $(\mathrm{L}=4000 \mathrm{~mm})$

\begin{tabular}{|c|c|c|c|c|c|}
\hline Type of c/s & $\begin{array}{c}\text { Critical load in buckling } \\
\text { (FEM) kN }\end{array}$ & $\begin{array}{c}\text { Critical load in } \\
\text { buckling (AISC) } \\
\text { kN }\end{array}$ & $\begin{array}{c}\text { \% Difference } \\
\text { with FEM }\end{array}$ & $\begin{array}{c}\text { Critical load in } \\
\text { buckling } \\
\text { (EUROCODE 4) } \\
\text { kN }\end{array}$ & $\begin{array}{c}\text { \% Difference } \\
\text { with FEM }\end{array}$ \\
\hline Circular & 6200 & 6386 & $-3.0 \%$ & 5956 & $3.93 \%$ \\
\hline Square & 6458 & 6786 & $-5.07 \%$ & 6298 & $2.47 \%$ \\
\hline
\end{tabular}




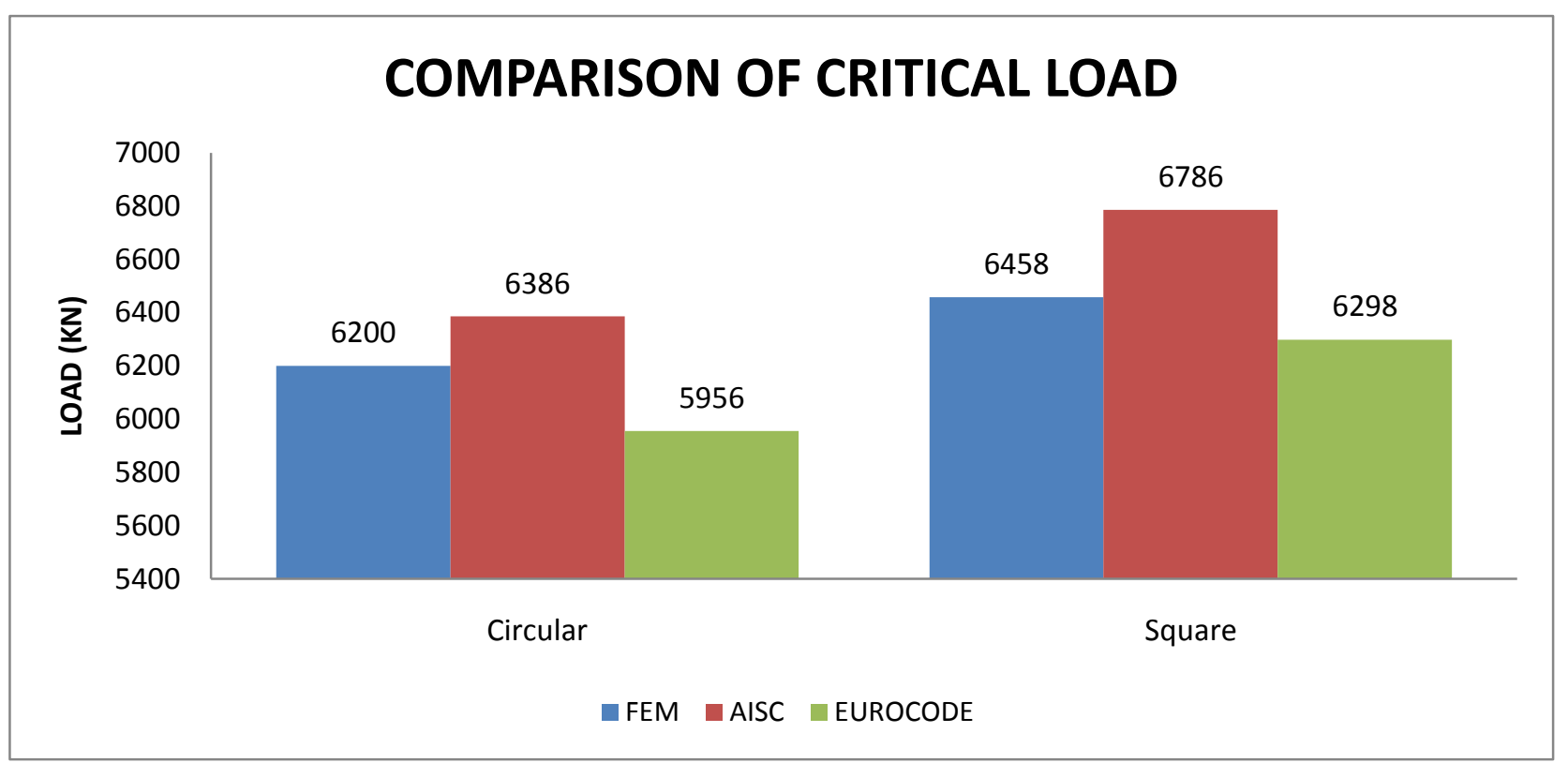

Chart 5. Critical load comparisons of slender CFST columns ( $\mathrm{L}=4000 \mathrm{~mm})$

\section{CONCLUSION}

The use of CFST columns has increased due to ease and speed in construction. Codal provisions in Indian standards are under revision and draft code of IS 11384 is silent about CFT without any reinforcement.

The attempt has been made in this paper to perform the finite element analysis on CFST columns and to verify results with codal provisions given in AISC and Euro.

The research finding indicates that the circular cross section of CFST column is effective in resisting axial deflection as well as strength compared to square cross section having equal steel material.

On comparison of finite element analysis results it is observed that the AISC code differs by 3 to $5 \%$ on higher side. The results given by Euro code 4 are rather closer to FEM solution in the range of 2 to $4 \%$.

Euro code 4 provisions can be safely adopted by BIS to estimate axial load capacities of short as well as long CFT columns containing no reinforcements.

\section{Acknowlwdgement}

I take this opportunity to express my deep sense of gratitude towards my guide Dr. M. R. Shiyekar, Professor, Applied Mechanics Department, Government College of Engineering, Karad. I extent my sincere thanks to Dr. A. T. Pise, Principal, Government College of Engineering, Karad and Dr. Y. M. Ghugal, Head, Applied Mechanics Department, Government College of Engineering, Karad for providing institutional facilities and extending all kinds of co-operation. I am thankful to all the faculty members of Applied Mechanics, Civil Engineering Department and Library whose guidance and help have been immensely useful in my work.

\section{REFERENCE}

[1] Schneider Stephen P., et al. October 1998“Axially loaded concrete-filled steel tubes", Journal of structural engineering, 1125.

[2] Z. Vrcelj, B. Uy, et al. 2002, "Strength of slender concrete-filled steel box columns incorporating local buckling", Journal of Constructional Steel Research, 58,275-300.

[3] Kenji Sakino, Hiroyunki Nakahara, ShosukeMorino, Isao Nishiyama, et al. Feb. 2004, "Behaviour of centrally loaded concrete filled steel tube short columns", Journal of structural engineering (ASCE), 130(2):180-188

[4] Schneider Stephen P., Donald R. Kramer and Douglas L. Sarkkinen, et al. August 1-6, 2004 "The design and construction of concrete-filled steel tube column frames", 13th World Conference on Earthquake Engineering Vancouver, B.C., Canada, Paper No. 252

[5] Kyung-Soo Chung, Jin-Ho Kim, and Jung-Han Yoo, et al. June 2012 "Prediction of Hysteretic Behavior of High-Strength Square Concrete-filled Steel Tubular Columns Subjected to Eccentric Loading", International journal of steel structure, Vol 12, No 2, 243-252.

[6] Sheet Ikhlas S., Umarani Gunasekaran, Gregory A. MacRae, et al. 30 March 2013. "Experimental investigation of CFT column to steel beam connections 
International Journal of Engineering Applied Sciences and Technology, 2019

Vol. 4, Issue 3, ISSN No. 2455-2143, Pages 85-93

Published Online July 2019 in IJEAST (http://www.ijeast.com)

under cyclic loading", Journal of constructional steel research.

[7] VimaVelayudhanIthikkat, Dipu V, et al. December (2014), "Analytical studies on concrete filled steel tubes", International journal of civil engineering and technology (IJCIET),Volume 5, Issue 12, pp. 99-106

[8] Pandu Ranga Kirankumar T, S.V.V.K. Babu, D. AdityaSai Ram, et al. 2016 "Comparative Study of Concrete Filled SteelTube Columns under Axial Compression", International Journal of Constructive Research in Civil Engineering (IJCRCE),Volume 2, Issue 2, PP 11-17.

[9] Krishan A.L., Troshkina E.A., Chernyshova E.P., et al. 2016 "Efficient Design of Concrete Filled Steel Tube Columns",Science Direct, Procedia Engineering 150 $1709-1714$.

[10] Kurian Shilpa Sara, Paulose Dinu, Sreepriyamohan, et al. 2016 "Study On Concrete Filled Steel Tube", IOSR Journal of Mechanical and Civil Engineering (IOSRJMCE), e-ISSN: 2278-1684, p-ISSN: 2320-334X, PP 25-33.

[11] Shah Darshika k., Vakil M.D., Patel M.N., et al. June 2014 "Parametric Study of Concrete Filled Steel Tube Column", IJEDR, Volume 2, Issue 2 (ISSN: 23219939)

[12] Singh Heaven, Gupta P.K., et al. 2014 "Numerical Modeling of Rectangular Concrete-Filled Steel Tubular Short Columns", Latin American Journals of Solids and Structures, 11, 1445-1462. 